\title{
Interleukin 28B Polymorphism as a Predictor of Response to Treatment of Egyptian HCV Patients Working in Nuclear Material Authority Hisham E Zidan ${ }^{1 *}$, Randa M Talaat ${ }^{2}$, Amal A A Ammar ${ }^{1}$, Moustafa A Sakr ${ }^{2}$
}

${ }^{1}$ Department of Medical Researches, Nuclear Material Authority, Cairo, ${ }^{2}$ Department of Molecular Diagnostics and Theraputics, Genetic Engineering and Biotechnology Research Institute (GEBRI), University of Sadat City, Menoufia, Egypt

Corresponding author: Hisham E Zidan, email: hz1616@yahoo.com

\begin{abstract}
Background: A Single nucleotide polymorphism upstream of the interferon- $\lambda 3$ gene (IFNL3; formerly referred to IL28B), strongly linked to unprompted and treatment-induced HCV infection clearance. Interleukin 28B genotype predictive value over the outcome interferon- $\alpha /$ ribavirin treatment was assessed carefully and contrasted with virological predictors

Objective: The study aimed to evaluate IL-28B rs12979860 polymorphism in the reaction of HCV patients with directacting antiviral (DAA) regimens (sovosbuvir) and ribavirin therapy and the allele frequencies of this gene in Egyptian HCV patients working in the Egyptian Nuclear Materials Authority contrasted to healthy control.

Subjects and Methods: The study was conducted on randomly chosen fifty Egyptian patients infected with genotype 4 HCV aged 30 or more and received antiviral therapy (sovosbuvir and ribavirin) before six months or more. Another Fifty age and gender matched apparantely healthy individuals were also selected as a control group. The study was carried out in accordance with the ethical principles and guidelines of the Declaration of Helsinki and a written informed consent was obtained from all subjects.

Results:IL-28B genotype CC was found in 34.6\% of patients, while CT and TT genotypes were identified in 42.3 and $23.1 \%$ of patients, respectively. Forty (40\%) patients achieved an SVR, whereas ten (20\%) did not. Of the 40 patients with an SVR, 12 had genotype CC, 25 had genotype CT, and 3 had genotype TT. CT genotype patients has achieved considerably higher SVR rates (62.5\%) compared with CC (30\%) and TT patients $(7.5 \%)$.

Conclusion: Polymorphism Il-28B is an autonomous predictor of SVR to Peg IFN / RBV in patients with genotype 4 in Egyptian HCV favorable.
\end{abstract}

Keywords: Interleukin 28B, Hepatitis C, Sofosbuvir.

\section{INTRODUCTION}

According to the WHO There are about 150 million $\mathrm{HCV}$-infected people who make up $3 \%$ of the population of the world. About 3:4 million fresh HCV patients are diagnosed each year ${ }^{(\mathbf{1})}$. Approximately 90 percent of all HCV patients are genotype 4 (HCV g4) ${ }^{(2)}$.

Hepatitis $\mathrm{C}$ virus is one of main causes for liver cirrhosis and subsequent growth of hepatocellular carcinoma (HCC). This often leads to failure of the liver and therefore transplantation of liver ${ }^{(3)}$.

The pathogenesis continues uncertain, but it is possible that not only the virus but also the virus' interaction with immune system of the host is important in determining the infection course and treatment reaction (4). Cytokines have recently recognized functional gene polymorphisms such as IFN- $\lambda$ which shows possible relations among these genotypes and the clinical results of liver disease linked to $\mathrm{HCV}^{(5)}$.

Exposure to radiation was related to enhanced HCC risk, specially among those affected by HBV or HCV infection, alcohol consumption, and smoking habit, even for non-predisposing variables ${ }^{(6)}$.

However, chronic and acute radiation exposure seems to have a distinct connection with cirrhosis of the liver, a frequent cause of proliferation of liver cells. Andersson et al. ${ }^{(7)}$ reported that there is no enhanced risk of cirrhosis for bomb irradiation in the 11 fold rise in cirrhosis in Danish individuals subjected to thorotrast. Thus, while chronical exposure to elevated doses of radiation can trigger both genetic alteration and hepatocyte cell proliferation leading to severe HCC, acute exposure to radiation at concentrations encountered by survivors of a bomb can only trigger the first of these occurrences. Thus, acute, unlike chronic, radiation exposure may require an additional factor of risk for developing of $\mathrm{HCC}{ }^{(8)}$. Treatment with pegylated interferon plus ribavirin PEG IFN / RBV is the norm for chronic HCV infection). However, this therapy results in continuous SVR reaction in only about $40 \%$ of genotype $1 \mathrm{HCV}$ patients and in $\sim 60 \%$ of those with genotype 4 , whereas over $80 \%$ of genotypes 2 or 3 achieve $S V R{ }^{(9)}$.

Recently, many antiviral effectors drugs have been developed for the treatment of HCV infection. One of the approved direct- acting antiviral drugs (DAA) is daclatasvir (DCV) in combined with sofosbuvir (SOF) with or without ribavirin for treatment of genotype 3 $\mathrm{HCV}$ infection. DCV is a potent, pan- genotypic inhibitor of the HCV NS5A protein and SOF is a pan- 
genotypic nucleotide analog inhibitor ofthe HCV NS5B RNA polymerase ${ }^{(\mathbf{1 0 , 1 1 )}}$.

Interleukin- 28B (IL- 28B) is a cytokine gene which encodes a protein interferon $\lambda 3$ (IFNL3) 12 and IL- 28B gene recently rebaptised as interferon $\lambda 3$. Cytokines are antiviral effectors, which induce an inflammatory reactionas a predominant mechanism of host defense against infections ${ }^{(\mathbf{1 2})}$.

It is conveyed by mononuclear peripheral blood cells dendritic cells after viral infection. IL-28B exhibits antiviral activity, having an impact on the natural clearance of $\mathrm{HCV}^{(13)}$.

Using IL-28B polymorphisms as a predictive instrument will have a significant effect on chronic HCV infection therapy strategies regarding to emerging therapies and direct-acting agents. It can assist to identify patients who are likely to have success with treatment ${ }^{(\mathbf{1 4})}$.

\section{SUBJECTS AND METHODS}

Fifty Egyptian patients infected with genotype 4 HCV were randomly chosen from Nuclear Materials Authority, Egypt. They were aged 30 or more, infected with HCV alone (no HBV or HIV) and received antiviral therapy before six months or more. Another fifty age and gender matched individuals were also selected randomly as a control group.

\section{Ethical approval:}

The study protocol was carried out in accordance with the ethical principles and guidelines of the Declaration of Helsinki and a written informed consent was obtained from all subjects. The study was approved by the Ethics Board of Sadat University.

Patients of the study were classified into two groups according to the response to therapy. The first group included fourty patients who received the therapy and had negative HCV-RNA after not less than 6 months of completion of a 12-week treatment course with DAAs. The second group included ten non responders' patients to the therapy and no disappearance of HCV-RNA at the end of treatment.

Two samples of blood were gathered from each patient and control. The first sample was left to clot at room temperature, centrifuged at 4000-6000 rpm; and serum was separated for biochemical (SGPT and SGOT) analysis. The second sample was collected in a clean and dry vacutainer tube with ethylene diamine tetra acetic acid (EDTA) anticoagulant for hematology analysis (CBC) and IL28B SNP called rs12979860 genotypes distribution study.

Dna extraction was performed using the G$\operatorname{spin}^{\mathrm{TM}}$ complete DNA extraction kit as per the manufacturer's spain cat no 17045 directions. Samples were lysed and the DNA was captured on the spin columns provided. The DNA was washed, eluted and then stored at $-20^{\circ} \mathrm{C}$ until used in PCR amplification. IL28B Genotyping via PCR-RFLP:

Genotyping for the IL-28B rs12979860 polymorphism was performed by means of PCR-based restriction fragment length polymorphism (RFLP) assay. According to the manufacturer's instructions, genomic DNA was obtained from entire blood samples using QIAamp DNA Blood Mini Kit (Qiagen, Milan, Italy).

For rs12979860, oligonucleotide primers used were: $5^{\prime}$ GCTTATCGCATACGGCTAGG-3' and the reverse primer: 5'-AGGCTCAGGGTCAATCACAG-3'. The PCR amplification was performed out in a total volume of $10 \mu \mathrm{l}$ with $10 \mathrm{mmol} / \mathrm{l}$ Tris- $\mathrm{HCl}(\mathrm{pH} 8.3), 50 \mathrm{mmol} / \mathrm{l}$ $\mathrm{KCl}$, Tween-20 0.01\%, $0.2 \mathrm{~mol} / \mathrm{l}$ deoxyribonucleotides, 2-4 pmol of each primer, $2.0 \mathrm{mmol} / \mathrm{l} \mathrm{MgCl} 2$, and $0.5 \mathrm{U}$ hot-start Taq DNA polymerase (RighTaq; Euroclone, Milan, Italy). $10 \mathrm{ng}$ of genomic DNA of samples have been subjected to 40 denaturation cycles at $95^{\circ} \mathrm{C}$ for 30 $\mathrm{s}$ of $62{ }^{\circ} \mathrm{C}$ for $30 \mathrm{~s}$ of annealing and $72{ }^{\circ} \mathrm{C}$ of elongation for $30 \mathrm{~S}$ (at $95^{\circ} \mathrm{C}$ for $30 \mathrm{~s}$ ), annealing (at $62^{\circ} \mathrm{C}$ for $30 \mathrm{~s}$ ), and elongation (at $72^{\circ} \mathrm{C}$ for $30 \mathrm{~s}$ ) using a Techne TC412 (Ghent, Belgium) thermal cycler ${ }^{(15)}$. Then RFLP was made as follows: $10 \mu$ of the amplicons were digested at $60^{\circ} \mathrm{C}$ overnight with $1 \mathrm{U}$ of the BstU-I restriction endonuclease (New England Bioloabs; Hitchin, UK).

The digested parts were $135+82+25 \mathrm{bp}$ in the c allele and $160+82$ bp in the $\mathrm{T}$ allele variant respectively. The reactions were performed in $50 \mu 1$ total volume and consist of the master mix plus template DNA. The amplicons were isolated by electrophoresis of $2 \%$ agarose gel and stained with $05 \mathrm{mg} / 1$ ethidium bromide. On agarose gel, both homozygous (CC and TT) genotypes and heterozygous (CT) genotypes were identified.

\section{Statistical analysis}

Using a social sciences statistical package (SPSS Inc. Released 2008, SPSS Statistics for Windows, Version 22.0, Chicago, USA), the informations were gathered, tabulated and evaluated on an IBM compatible computer. The C2-test was conducted to study the association between two qualitative variables. Fisher's exact test was used in the analysis of $2 \times 2$ contingency tables. The Student t-test was for comparison between two groups having normally distributed quantitative variables.

The Mann-Whitney U-test was conducted as a nonparametric test of significance for comparison between two groups having not normally distributed quantitative variables. Analysis of variance was used as a parametric test for comparison between more than two groups having normally distributed quantitative variables. The Kruskal-Wallis test was used as a nonparametric test of significance for comparison 
between more than two groups having not normally distributed quantitative variables. Regression analysis is a statistical process for estimating the relationships among variables ${ }^{(15)}$.

\section{RESULTS}

Table (1): Comparison between HCV patients and controls regarding to the laboratory findings.

\begin{tabular}{|c|c|c|c|c|}
\hline \multirow{2}{*}{ Parameters } & \multicolumn{2}{|c|}{ Mean \pm SD } & \multirow{2}{*}{ t-test } & \multirow{2}{*}{ P Value } \\
\cline { 2 - 3 } & Control & Patients & & \\
\hline TLC $\left(\mathbf{1 0}^{\mathbf{3}} / \boldsymbol{\mu L}\right)$ & $4.99 \pm 1.36$ & $6.74 \pm 1.89$ & 5.31 & $<0.001^{\mathrm{HS}}$ \\
\hline HB $(\mathbf{g} / \mathbf{d L})$ & $14.42 \pm 1.92$ & $13.63 \pm 1.97$ & 2.03 & $<0.05^{\mathbf{S}}$ \\
\hline PLT $(\mathbf{1 0} / \mathbf{c m m})$ & $229.62 \pm 39.82$ & $220.60 \pm 57.54$ & 0.91 & $>0.05^{\mathrm{NS}}$ \\
\hline AST $(\mathbf{U} / \mathbf{L})$ & $25.36 \pm 3.76$ & $30.68 \pm 3.59$ & 2.67 & $<0.05^{\mathbf{S}}$ \\
\hline ALT $(\mathbf{U} / \mathbf{L})$ & $23.12 \pm 3.68$ & $30.58 \pm 5.85$ & 3.24 & $<0.001^{\mathrm{HS}}$ \\
\hline
\end{tabular}

- ${ }^{\text {NS }}$ : Non significant at P-value $\geq 0.05 \quad$ s $:$ Significant at P-value $<0.05$

-\%: percent of allele within group _ $\quad{ }^{\text {HS }}$ : Highly significant at P-value $<0.01$

${ }^{\text {a }}$ : Dominant model, (hybrid type+ wild type) vs. homozygous type

${ }^{\mathrm{b}}$ : Recessive model, wild type vs. (homozygous type + hybrid type)

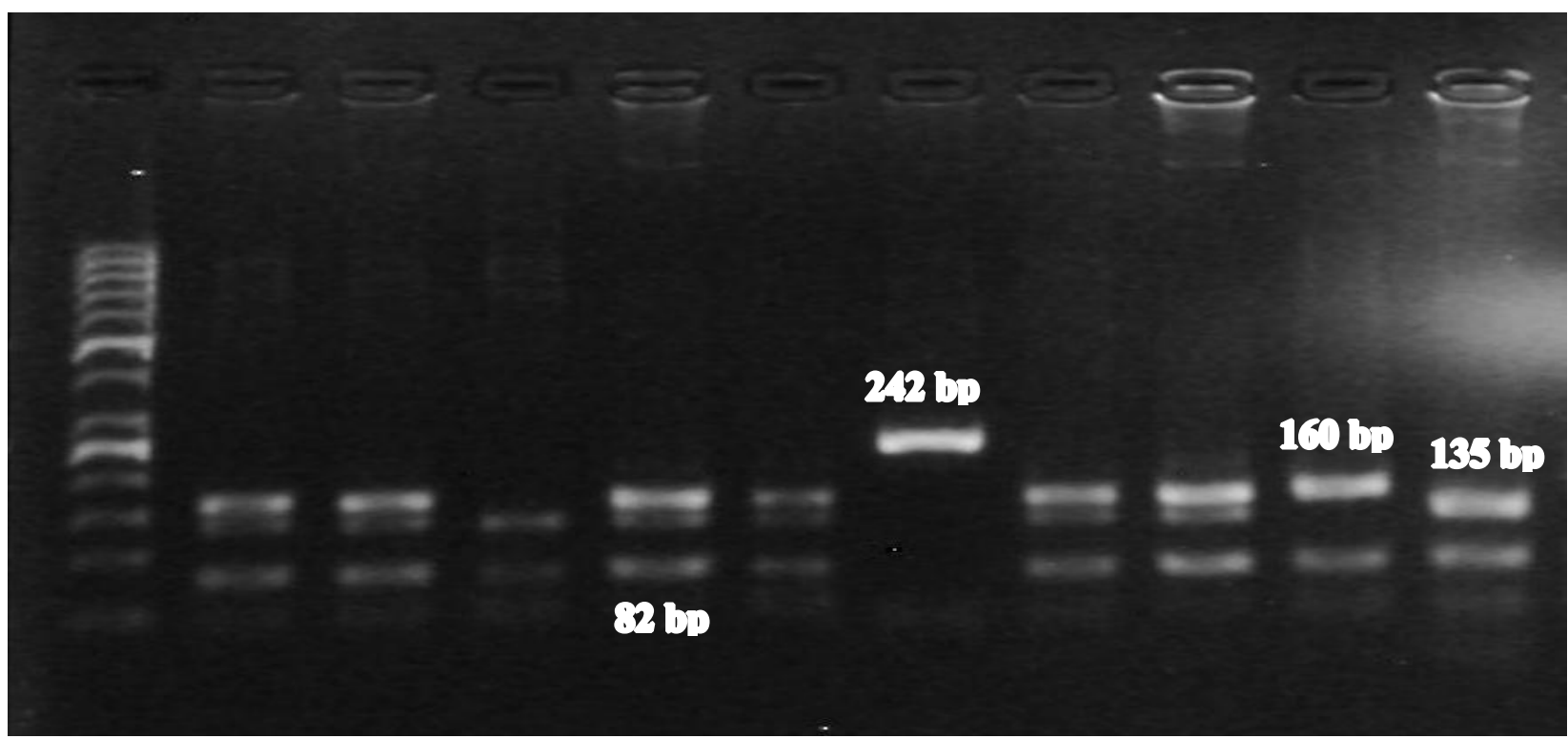

Figure 1: PCR-RFLP products on agarose gel electrophoresis illustrating for the interleukin 28B gene polymorphism.

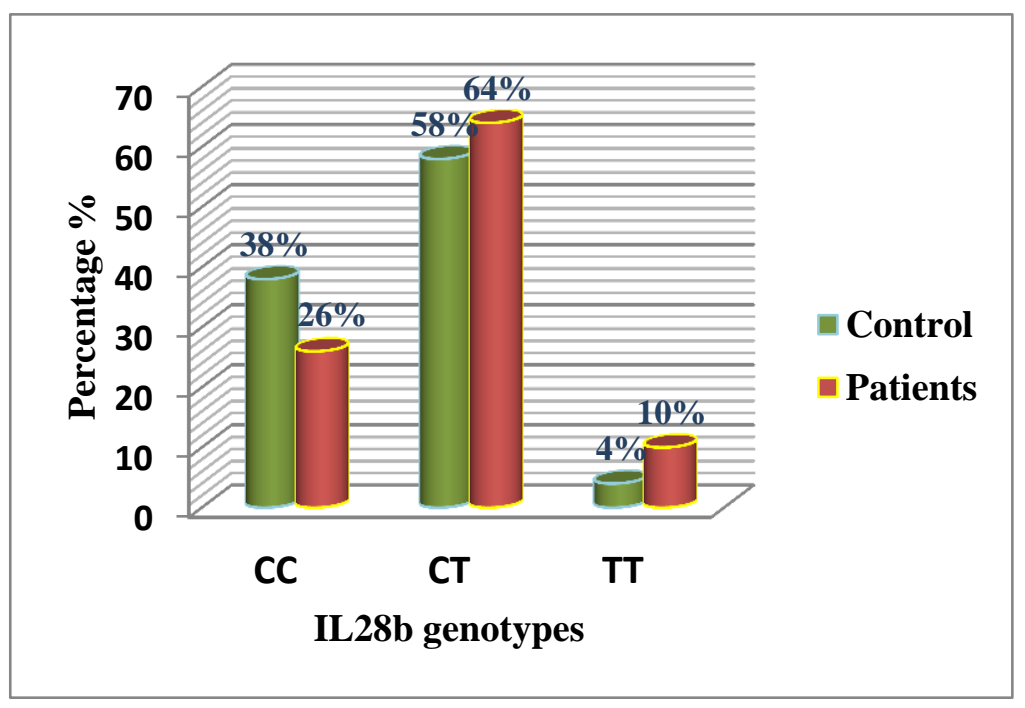

Figure 2: Distribution of the interleukin 28B (IL-28B) genotypes among hepatitis C virus (HCV) patients and healthy controls. 
ejhm.journals.ekb.eg

Table 2: Genotypes distribution and of IL28B polymorphism in both groups

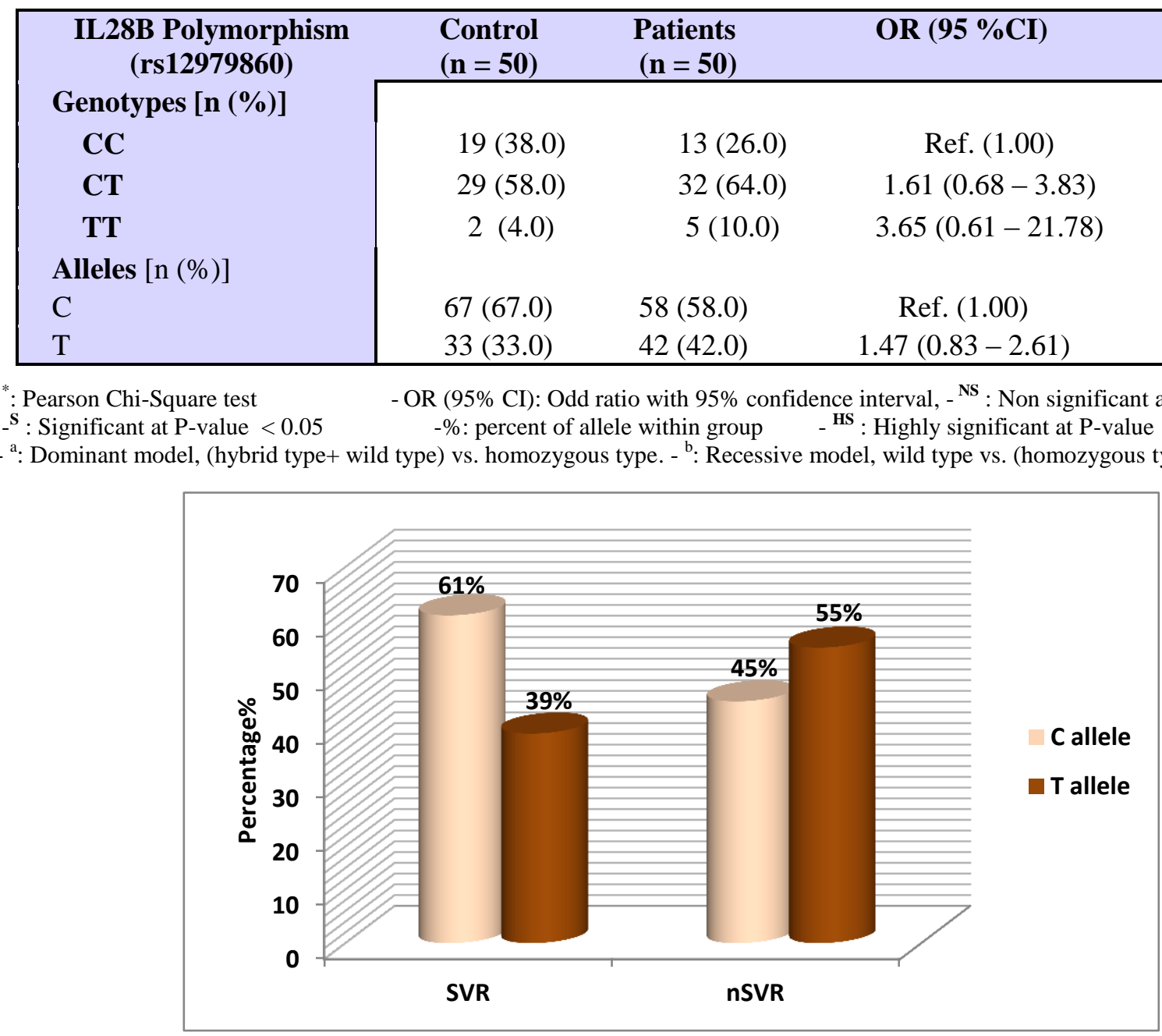

Figure 3: Alleles frequency of IL28b polymorphism (rs12979860) in SVR and nSVR groups:

Table 3: Genotypes distribution and allele frequencies of IL28B polymorphism (rs368234815) in SVR and nSVR groups

\begin{tabular}{|c|c|c|c|c|c|}
\hline & $\begin{array}{l}\text { IL28B Polymorphism } \\
\text { (rs12979860) }\end{array}$ & $\begin{array}{c}\text { SVR } \\
(n=40)\end{array}$ & $\begin{array}{l}\text { nSVR } \\
(\mathrm{n}=10)\end{array}$ & OR (95 \% CI) & P-value * \\
\hline \multirow[t]{3}{*}{ Genotypes [n (\%)] } & $\mathrm{CC}$ & $12(30 \%)$ & $1(10 \%)$ & Ref. (1.00) & - \\
\hline & CT & $25(62.5 \%)$ & $7(70 \%)$ & $3.63(0.37-30.49)$ & $0.28^{\mathrm{NS}}$ \\
\hline & TT & $3(7.5 \%)$ & $2(20 \%)$ & $8.0(0.53-120.66)$ & $0.13^{\mathrm{NS}}$ \\
\hline \multirow[t]{3}{*}{ Dominant model ${ }^{\text {a }}$} & $\mathrm{CC}$ & $12(92.3)$ & $1(7.7)$ & $\operatorname{Ref}(1.00)$ & \\
\hline & $\mathrm{CT}+\mathrm{TT}$ & $28(75.7)$ & $9(24.3)$ & $3.86(0.44-33.91)$ & $0.22^{\mathrm{NS}}$ \\
\hline & $\mathrm{CC}+\mathrm{CT}$ & $37(82.2)$ & $8(17.8)$ & $\operatorname{Ref}(1.00)$ & \\
\hline \multirow{3}{*}{$\begin{array}{l}\text { Recessive model }^{\text {b }} \\
\text { Alleles }[\mathrm{n}(\%)]\end{array}$} & TT & $3(60.0)$ & $2(40.0)$ & $3.86(0.44-33.91)$ & $0.075^{\mathrm{NS}}$ \\
\hline & $\mathrm{C}$ & $49(61.0)$ & $9(45.0)$ & Ref. (1.00) & \\
\hline & $\mathrm{T}$ & $31(39.0)$ & $11(55.0)$ & $1.93(0.72-5.19)$ & $0.049^{\mathrm{S}}$ \\
\hline
\end{tabular}

SVR, sustained viral response, NSVR, Nonsustained viral response, ": Pearson Chi-Square test, \%: percent of allele within group , Ns: Non-significant at P-value $\geq 0$, , : Significant at P-value less than 0.05

- ${ }^{\mathrm{HS}}$ : Highly significant at P-value $<0.01$, OR $(95 \% \mathrm{CI})$ : Odd ratio with $95 \%$ confidence interval

- a : Dominant model, (hybrid type+ wild type) vs. homozygous type, ${ }^{\text {b}}$ : Recessive model, wild type vs. (homozygous type + hybrid type) 
Table 4: Comparison between IL28B genotypes and laboratory parameters for patients:

\begin{tabular}{|c|c|c|c|c|c|}
\hline & \multicolumn{3}{|c|}{ IL28B genotypes } & \multirow{2}{*}{$\begin{array}{c}\text { Kruskal-Wallis } \\
\text { Test }\end{array}$} & \multirow{2}{*}{ P Value } \\
\hline & $\mathrm{CC}(\mathrm{N}=13)$ & CT $(\mathbf{N}=32)$ & TT $(\mathbf{N}=5)$ & & \\
\hline Age $(\mathrm{X} \pm \mathrm{SD})$ & $49.15 \pm 9.43$ & $49.78 \pm 9.84$ & $50.40 \pm 10.64$ & 0.9 & $0.956^{\mathrm{NS}}$ \\
\hline TLC $(\mathrm{X} \pm \mathrm{SD})$ & $6.59 \pm 1.36$ & $7.01 \pm 1.60$ & $5.38 \pm 1.04$ & 2.814 & $0.245^{\mathrm{NS}}$ \\
\hline HB (X土SD) & $13.61 \pm 2.62$ & $13.66 \pm 1.75$ & $13.56 \pm 1.82$ & 0.368 & $0.832^{\mathrm{NS}}$ \\
\hline Platelets (X士SD) & $232.54 \pm 9.16$ & $221.31 \pm 53.18$ & $185.00 \pm 7.34$ & 2.008 & $0.366^{\mathrm{NS}}$ \\
\hline AST $(\mathrm{X} \pm$ SD) & $28.46 \pm 2.42$ & $30.50 \pm 2.73$ & $37.60 \pm 1.59$ & 0.151 & $0.927^{\mathrm{NS}}$ \\
\hline ALT (X+SD) & $28.00 \pm 4.45$ & $30.00 \pm 5.48$ & $41.00 \pm 2.80$ & 1.943 & $0.379^{\mathrm{NS}}$ \\
\hline
\end{tabular}

TLC, total leukocytic count; Hb, hemoglobin; PLT, platelets; AST, aspartate aminotransferase; ALT, alanine aminotransferase.

\section{DISCUSSION}

The mean age was $41.28 \pm 8.11$ and $48.18 \pm 8.15$ for control and patients respectively, and the difference is statistically significant $(\mathrm{p}<0.001)$.

Among the baseline laboratory values, alanine aminotransferase (ALT) and aspartate aminotransferase (AST) levels were significantly higher in patients than in controls $(\mathrm{P}<0.01)$. Hematology values shown that there is a significant difference as regards to $\mathrm{HB}(\mathrm{P}<0.05)$ as well as highly significant difference regarding to TLC $(\mathrm{P}<0.01)$, and non-significant difference regarding to PLT $(\mathrm{P}>0.05)$, between control and patients' group.

Agarose gel electrophoresis illustrated the PCRRFLP products for the IL28b gene polymorphism. Lane 1 corresponds to $50 \mathrm{bp}$ molecular weight marker, Lane 7 is nondigested PCR product at $242 \mathrm{bp}$, Lane 10 correspond to blood samples from homozygous CC participants at $160 \mathrm{bp}$ and $85 \mathrm{bp}$. Lanes 4 and 11 correspond to blood samples from homozygous TT participants at $135 \mathrm{bp}$. Lanes 2, 3,5,6,8 and 9, correspond to blood samples from heterozygous CT participants at 160, 135 and 85 bp (Fig 1). The CC genotype occurred more frequently in control group compared to patients group (19/50 vs. 13/50), unlike $\mathrm{CT}$ and TT genotypes that were more frequent in patients compared to control (32/ 50 and 2/50 vs. $29 / 50$ and $5 / 50$ respectively), but this was statistically non significant (Table 2).

This study shows the comparison between different IL28b genotypes (CC, CT, and TT) in HCV patients where is no significant difference as regards Age, TLC, HB, PLTs, AST \& ALT (Table 4).

In this study, the distribution of IFNL3 genotypes in genotype 4 Egyptian patients showed that almost half of them were of the CT genotype (58\%) followed by CC (38\%) while TT had the least expression (4\%). The CC genotype constituted $\approx 26 \%$ of the control group, while the TT genotype constituted $\approx 10 \%$ and the heterozygous genotype $\mathrm{CT} \approx 64 \%$ (Figure 2).

This study showed that the CC genotype of rs 12979860 , which achieved SVR, was $62.5 \%$, which is significantly higher compared with CT (30\%) and TT $(7.5 \%)$ genotypes.
The $\mathrm{C}$ allele was significantly higher in responders (61\%) than in nonresponders (45\%) (Fig. 3).

Similar findings have been noted by Asselah et al. ${ }^{(18)}$ who discovered that the reaction rates for genotypes CT, CC and TT were 46.5, 81.8, and 29.4\% respectively. Also, Khairy et al. ${ }^{(17)}$ discovered that the reaction rates were 50, 47.4 in a research performed on Egyptian patients (Table 3). In studies conducted on $\mathrm{HCV}$ genotype 1 patients in different geographical areas, patients with the $\mathrm{CC}$ genotype achieved SVR more frequently than CT or TT subgroups. Ge et al. ${ }^{(22)}$ discovered that CC patients had SVR rates of $77 \%$ in whites and $53 \%$ in African Americans. Also, Mangia et al ${ }^{(23)}$ reported that $82 \%$ of patients with the CC genotype achieved an SVR among HCV infected patients genotype $2 / 3$, compared to $75 \%$ of the CT \& $58 \%$ of TT genotypes.

Attallah et al. ${ }^{(16)}$ also discovered that RFLP results showed that IL28B rs12979860 CT genotype is the most common genotype in Egyptian patients with HCV G-4 infections. The CC genotype constituted $18 \%$ of the samples of study, whereas the TT genotype was $9 \%$ and the heterozygous genotype CT $73 \%$.

Nearly comparable results were reported in many latest Egyptian researches. For example, Khairy et al. ${ }^{(17)}$ Who revealed that the frequency of genotype IL28 in 263 acute HCV genotype 4 Egyptian patients was $56 \%$ for CT, followed by $25 \%$ for CC, whereas TT had the smallest possible expression (19\%). These findings matched the 2012 survey of the de nicola group, which included 128 patients with genotype 4; $68 \%$ of Egyptians who showed $63 \%$ of CT $14 \%$ TT and $23 \%$ of CC. Also, Asselah ${ }^{(18)}$ and colleagues researched 164 genotype patients in $443 \%$ of Egyptians and discovered a distinction in the distribution of IL28B genotype among Egyptians. In a research on genotype 4 El-Awady ${ }^{(\mathbf{1 9})}$ and peers also discovered that the frequencies of genotypes were $48 \%$ CC, $14 \%$ TT and 38\% CT for their research in 2012. Hendy et al. ${ }^{(20)}$ found that the incidence of CT, CC, and TT genotypes respectively to be $51 \%, 39 \%$, and $10 \%$.

In the present research, there were 58,38 , and 4 percent frequencies of IL28B genotypes CT, CC, and 
TT in healthy control. The frequency of the IL28B CC genotype was lower in $\mathrm{HCV}$ patients compared to 26 vs 38 percent in controls. However, there was significant difference between $\mathrm{HCV}$ patients and controls as regards the IL- 28B alleles, as the frequency of the $\mathrm{C}$ allele in $\mathrm{HCV}$ patients was smaller than in healthy controls (58 vs. 67\%) and the T allele was higher in HCV patients than in controls (42 vs. $33 \%$ ) (Table 2).

In agreement with this study is the one by Par $\boldsymbol{e t}$ al. ${ }^{(21)}$ who reported that the frequency of the IL-28B $\mathrm{CC}$ genotype was lower in Hepatitis $\mathrm{C}$ patients than in controls; it may be considered safe from chronic $\mathrm{HCV}$ infection. In the present study after therapy, $40(80 \%)$ patients among the overall $50 \mathrm{HCV}$ patients achieved SVR (responders), and the remaining 10 (20\%) patients failed to respond. This finding was supported by previous studies by Al Ashgar and colleagues.

\section{CONCLUSION}

IL28B genotypes are heavily linked to therapy effectiveness in genotype 4 patients of HCV infection. Therefore, IL28B genotyping is helpful to predict the result of direct acting antivirals. In addition to enhancing the likelihood of SVR determining IL28B SNPs before therapy is started, it will be cost-effective and decrease adverse effects.

\section{REFERENCES}

1. WHO (2014): Hepatitis C. Available at: http://www.who.int/ mediacentre/factsheets/fs164/en/index.html.

2. El-Raheem H (2017): Interleukin-28B polymorphism is a pharmacogenetic predictor during sofosbuvir plus pegylated interferon and ribavirin therapy for chronic hepatitis $\mathrm{C}$ in Egyptian patients. Journal of Pharmacogenomics \& Pharmacoproteomics., 8(1):1-5.

3- Sarrazin C, Susser S, Doehring A et al. (2011): Importance of IL28B gene polymorphisms in hepatitis C virus genotype 2 and 3 infected patients. J Hepatol., 54:415- 421.

4- Rehermann B (2000): Interaction between the hepatitis $C$ virus and the immune system. Semin Liver Dis., 20:127- 141.

5- Sarrazin C, Hezode C, Zeuzem S, Pawlotsky J (2012): Antiviral strategies in hepatitis C virus infection. J Hepatol., 56: $S 88-100$.

6- Ohishi W, Fujiwara S, Cologne JB, Suzuki G, Akahoshi M, Nishi N, Tsuge M, Chayama K (2011): Impact of radiation and hepatitis virus infection on risk of hepatocellular carcinoma. Hepatology, 53:1237-1245.

7- Androneson A, Robe C, Berbecar V et al. (2018): Nephrology Dialysis Transplantation. doi:10.1093/ndt/gfx140

8- Sharp GB, Mizuno T, Cologne JB, Fukuhara T, Fujiwara S, Tokuoka S et al. (2003): Hepatocellular carcinoma among atomic bomb survivors: significant interaction of radiation with hepatitis C virus infections. Int J Cancer,103:531-7.
9- Hadigan C, Kottilil S (2011): Hepatitis C virus infection and coinfection with human immunodeficiency virus: challenges and advancements in management. JAMA., 306:294-301.

10- Gao M (2013): Antiviral activity and resistance of HCV NS5A replication complex inhibitors. Curr Opin Virol., 3:514- 520.

11- Sofia MJ, Bao D, Chang W et al. (2010): Discovery of a $\beta$-d20-deoxy-20- $\alpha$-fluoro-20- $\beta$-Cmethyluridine nucleotide prodrug (PSI-7977) for the treatment of hepatitis C virus. J Med Chem., 53:7202-7218.

12- Khan AJ, Saraswat VA, Ranjan P, Parmar D, Negi TS, Mohindra S (2018): Polymorphism in interferon $\lambda 3$ interleukin-28B gene and risk to noncirrhotic chronic hepatitis $\mathrm{C}$ genotype 3 virus infection and its effect on the response to combined daclatasvir and sofosbuvir therapy. J Med Virol.,1-9.

13- Par A, Kisfali P, Melegh B, Vincze A et al. (2011): Cytokine (IL-10, IL-28B and LT-A) gene polymorphisms in chronic hepatitis $\mathrm{C}$ virus infection. Clin Exp Med., 5:9-19.

14- Ge D, Fellay J, Thompson AJ, Simon JS, Shianna KV, Urban TJ et al. (2009): Genetic variation in IL28B predicts hepatitis C treatment-induced viral clearance. Nature, 461:399401.

15- Fabris C, Falleti E, Cussigh A, Bitetto D, Fontanini E, Bignulin S et al. (2011): IL-28B rs12979860 C/T allele distribution in patients with liver cirrhosis: role in the course of chronic viral hepatitis and the development of HCC. J Hepatol ., 54:716-722.

16- Attallah AM, Omran D, Omran MM et al. (2018): Extracellular matrix proteins substantiate il-28b t allele effect on histological outcome of chronic hepatitis C. Ann Hepatol.,17(4):569-576.

17- Khairy M, Fouad R, Mabrouk M et al. (2013): The impact of interleukin $28 \mathrm{~b}$ gene polymorphism on the virological response to combined pegylated interferon and ribavirin therapy in chronic HCV genotype 4 infected Egyptian patients using data mining analysis. Hepat Mon., 13:7.

18- Asselah T, De Muynck S, Broët P et al. (2012): IL28B polymorphism is associated with treatment response in patients with genotype 4 chronic hepatitis C. J Hepatol., 56:527-532.

19- El-Awady MK, Mostafa L, Tabll AA, Abdelhafez TH, Bader El Din NG, Zayed N et al. (2012): Association of IL28B SNP with progression of Egyptian HCV genotype 4 patients to end stage liver disease. Hepat Mon., 12:271-277.

20- Hendy O, Abd El Moneam E, Al Shafie M, El-Sabawy M, Rady M, EI Baz S (2011): Role of IL28B gene polymorphisms in response to the standard of care treatment in Egyptian patients with chronic HCV genotype 4. Life Sci J., 8:908-915.

21- Par A, Kisfali P, Melegh B, Vincze A et al. (2011): Cytokine (IL-10, IL-28B and LT-A) gene polymorphisms in chronic hepatitis $C$ virus infection. Clin Exp Med., 5:9-19.

22- Ge D, Fellay J, Thompson AJ, Simon JS, Shianna KV, Urban TJ et al. (2009): Genetic variation in IL28B predicts hepatitis C treatment-induced viral clearance. Nature, 461:399401.

23- Mangia A, Thompson AJ, Santoro R, Piazzolla V, Tillmann HL, Patel K et al. (2010): An IL28B polymorphism determines treatment response of hepatitis $\mathrm{C}$ virus genotype 2 or 3 patients who do not achieve a rapid virologic response. Gastroenterology, 139:821-827. 